\title{
Lactational responses of grazing dairy cows to rumen-protected methionine
}

\author{
H Rulquin*, L Delaby \\ Station de recherches sur la vache laitière, Centre de recherches Inra de Rennes, \\ 35590 Saint-Gilles, France
}

(Received 9 April 1997; accepted 14 May 1997)

\begin{abstract}
Summary - Two groups of 18 Prim'Holstein cows grazed on a rye-grass meadow during the second and third cycles according to a strip grazing system, at a grass regrowth age of about 1 month. During each cycle, the cows were administered either 0 or $13 \mathrm{~g} /$ day rumen-protected methionine according to a reverse design. The response to the methionine supplementation was the same in both cycles. The methionine supplementation reduced milk yield slightly but significantly ( $26.0 \mathrm{vs} 26.5 \mathrm{~kg}$ ) and increased the milk protein content $(31.4 \mathrm{vs} 30.6 \mathrm{~g} / \mathrm{kg}$ ). Milk fat content, fat and protein yields were not significantly modified. A rumen-protected methionine supplementation significantly increased plasma methionine concentration by $27 \%$. Based on the fact that milk protein yield was unchanged, it was concluded that methionine is not the most limiting amino acid at grazing.
\end{abstract}

milk composition / pasture / rumen-protected methionine / dairy cow

Résumé - Effets de l'apport de méthionine protégée sur les performances des vaches laitières au pâturage. Deux lots de 18 vaches de race Prim'Holstein (neuf multipares, neuf primipares) ont pâturé une prairie de ray-grass Anglais durant le deuxième et le troisième cycle selon la technique du pâturage rationné avec un âge des repousses d'environ 1 mois. Le chargement était respectivement de 6 et 5 vaches/hectare durant les deuxième et troisième cycles. L'apport de concentré s'est effectué individuellement à raison de $1 \mathrm{~kg}$ d'aliment par tranche de $3 \mathrm{~kg}$ de lait au-dessus de $20 \mathrm{~kg}$ lait pour les multipares et $17 \mathrm{~kg}$ pour les primipares avec un maximum de $5 \mathrm{~kg}$ et un minimum de $1 \mathrm{~kg}$. Durant chaque cycle les vaches ont reçu 0 ou $13 \mathrm{~g} /$ jour de méthionine protégée selon un schéma en inversion avec des périodes de $14 \mathrm{j}$. Les teneurs de l'herbe en MAT, matière organique, et en acides aminés n'ont pas varié entre les deux cycles, celles d'ADF et de NDF ont légèrement augmenté. La quantité d'herbe offerte était de 17,5 et $21,2 \mathrm{~kg} \mathrm{MS} / \mathrm{vache} / \mathrm{jour}$ durant les deux cycles respectivement. En complément les vaches ont ingéré 3,4 kg MS d'aliment concentré. La réponse à l'apport de méthionine a été la même durant les deux cycles. L'apport de méthionine a légèrement mais significativement diminué la production de lait $(26,0 \mathrm{vs} 26,5 \mathrm{~kg})$ et augmenté le taux protéique du lait (31,4 vs

\footnotetext{
* Correspondence and reprints

Tel: (33) 02992850 93; fax: (33) 02992851 01; e-mail: rulquin@st-gilles.rennes.inra.fr
} 
$30,6 \mathrm{~g} / \mathrm{kg}$ ). Le taux butyreux, la production de matières grasses, de protéines n'ont pas significativement été modifiés. L'apport de méthionine protégée a significativement accru de $27 \%$ la concentration de méthionine dans le plasma. Sur la base de la production de protéine qui n'a pas été modifiée, il est conclu que la méthionine n'est pas l'acide aminé le plus limitant au pâturage.

composition du lait / pâturage / méthionine protégée / vache laitière

\section{INTRODUCTION}

As a supplement to winter diets based on maize silage and soybean meal, rumen-protected methionine increases the milk protein content by 1 or $2 \mathrm{~g} / \mathrm{kg}$ (Rulquin and Delaby, 1994). The effect of methionine and lysine supplementation appears to be lower when it is associated with grass silage- or hay-based diets (Le Henaff et al, 1990). However, the small number of trials carried out with that type of diets (Girdler et al, $1988 \mathrm{a}, \mathrm{b})$ precludes extending those results to grass-based diets and even less to grazing because only one trial has been performed under such conditions (Brunschwig et al, 1995). In Europe, the grazing period is especially important because it can be as long as 6 to 8 months. Using well-protected methionine, we therefore set out to verify whether methionine supplementation was optimal under grazing conditions.

\section{MATERIALS AND METHODS}

\section{Sward}

The rye-grass swards (Lolium perenne) were prepared for grazing with 50 to $60 \mathrm{~kg} / \mathrm{N} / \mathrm{ha} / \mathrm{cycle}$ nitrogen fertilization. During the first cycle, these swards were grazed during the month of April. From the second cycle, these swards were grazed by an experimental 36-head herd according to the strip grazing system, with a grass regrowth age of about 1 month (25-30 days). The stocking rate was six cows/ha during the second cycle and five cows/ha during the third cycle.

\begin{abstract}
Animals
Two groups of 18 Prim'Holstein cows (nine primiparous and nine multiparous) as similar as possible were formed in late April with consideration of their performance in the previous weeks (13-26 April). Standard criteria were used: milk yield and composition, lactation number, lactation stage, live weight. At the beginning of the trial, the cows were on their 166th lactation day on average, were producing $30.5 \mathrm{~kg} /$ day milk $( \pm 6.7 \mathrm{~kg} / \mathrm{day})$ and weighed $615 \mathrm{~kg}( \pm 60 \mathrm{~kg})$. Both groups were given the rumen-protected methionine during the second and third cycles, according to a reverse design with 14-day periods, ie, approximately one reversal per cycle.
\end{abstract}

\section{Supplementation}

Concentrate supplementation (table I) was performed individually with $1 \mathrm{~kg}$ feed per $3 \mathrm{~kg}$ milk above $20 \mathrm{~kg}$ milk yield (pre-experimental reference) with ceiling and threshold levels of $5 \mathrm{~kg}$ and $1 \mathrm{~kg}$, respectively. This amount was kept constant throughout the trial. The supplementation threshold was set at $17 \mathrm{~kg}$ milk for primiparous cows. Mineral complement was systematically added by giving $500 \mathrm{~g}$ of a mineral concentrate (table I). Feed concentrates were given in individual troughs fitted with electronic gates. The animals had free access to the troughs after each milking.

The experimental treatment consisted in providing 0 or $13 \mathrm{~g} /$ day protected methionine (Smartamine M Rhône-Poulenc Animal Nutrition, Commentry, France), mixed with the other concentrates.

\section{Measurements}

Milk yield was recorded daily. The milk fat and protein contents were determined by infrared analysis (Milkoscan, Foss Electric, Hillerød, 
Table I. Composition (\% DM) and nutritive values of concentrates.

\begin{tabular}{|c|c|c|}
\hline & Concentrate & Minerals \\
\hline Wheat & 23.5 & 9.6 \\
\hline Maize grain & 24.1 & - \\
\hline Barley & 16.0 & - \\
\hline Fine wheat bran & - & 24.1 \\
\hline Maize gluten feed & - & 20.7 \\
\hline Soybean meal 48 & - & 3.9 \\
\hline Formaldehyde treated soybean meal $48^{1}$ & 30.5 & - \\
\hline Sugar beet molasses & 1.8 & 8.5 \\
\hline Tallow & 0.8 & - \\
\hline Minerals salts ${ }^{2}$ & 3.2 & 33.3 \\
\hline UFL (g/kg DM) & 1.14 & 0.72 \\
\hline PDIE (g/kg DM) & 188 & 72 \\
\hline PDIN (g/kg DM) & 179 & 84 \\
\hline LysDI (\%PDIE) ${ }^{3}$ & 6.69 & 6.52 \\
\hline MetDI (\%PDIE) ${ }^{3}$ & 1.63 & 1.84 \\
\hline
\end{tabular}

${ }^{1}$ Treated with $2 \%$ of formaldehyde on a raw matter basis.

${ }^{2}$ Supplying $10 \% \mathrm{P}, 15 \% \mathrm{Ca}, 7 \% \mathrm{Mg}$ micro-minerals and vitamins.

${ }^{3}$ Intestinal digestible content of Lys and Met calculated according to Rulquin et al (1993).

Denmark) of 10 consecutive milkings per week. Live weight was measured once a week. On the Thursday of the second week of each period, $10 \mathrm{~mL}$ blood were sampled from the caudal vein with a heparinized syringe. That sample was taken for plasma free amino acid analysis according to the method described by Pisulewski et al (1996).

Individual concentrate intake amounts were measured daily. A sample was collected every week for dry matter determination. That sample was preserved so as to compose a mean sample of the whole trial for standard chemical analyses.

Biomass (motor scythe; 6 bands of $10 \mathrm{~m} \times 0.5 \mathrm{~m}$ per hectare) and grass height (automatic rising plate meter (Urban and Caudal, 1990)) measurements were performed and grass samples were taken weekly on the part not yet grazed of the current sward. The height of the grass available was determined from 150 measurements/ha performed always following the same pattern, on the same day and over the same area as the biomass measurements.
Before pick-up, a grass sample was taken from each scything band and collected so as to obtain a $1-\mathrm{kg}$ sample for dry matter determination; that sample was preserved and collected with others for standard chemical analyses; a 2$\mathrm{kg}$ sample was frozen immediately after pick-up for amino acid analysis.

\section{Sample analysis}

Organic matter (OM) was determined by ashing for $5 \mathrm{~h}$ at $550^{\circ} \mathrm{C}$. The nitrogen content was obtained by the Kjeldhal method. The NDF and ADF contents were measured according to the method of Van Soest and Wine (1967) on a Fibertec $M$ extraction unit (Tecator, Denmark) as described by Giger and Pochet (1987). Cellulase digestibility was determined according to Aufrère and Demarquilly (1989). The amino acid content of plasma and grass was determined as described by Pisulewski et al (1996). 
Table II. Characteristics of grass at the entry in the paddock during the two grazing cycles.

\begin{tabular}{|c|c|c|}
\hline & Cycle 2 & Cycle 3 \\
\hline Number of samples & 4 & 4 \\
\hline Age of regrowth (day) & $28 \pm 3.8$ & $26 \pm 2.8$ \\
\hline Height $(\mathrm{cm})$ & $15.6 \pm 0.3$ & $14.7 \pm 4.0$ \\
\hline Biomass (kg DM/ha) & $2954 \pm 454$ & $2997 \pm 993$ \\
\hline OM (\%DM) & $89.1 \pm 8.5$ & $90.2 \pm 11.5$ \\
\hline $\mathrm{CP}(\% \mathrm{DM})$ & $19.9 \pm 0.3$ & $19.4 \pm 3.9$ \\
\hline NDF (\% DM) & $48.4 \pm 2.9$ & $52.2 \pm 1.2$ \\
\hline $\begin{array}{l}\text { ADF (\% DM) } \\
\text { OM digestibility }(\%) 1\end{array}$ & $\begin{array}{l}25.4 \pm 2.1 \\
80.9 \pm 2.1\end{array}$ & $\begin{array}{l}27.5 \pm 0.8 \\
75.0 \pm 2.0\end{array}$ \\
\hline \multicolumn{3}{|l|}{ Amino acids (g/16N) } \\
\hline Thr & 5.23 & 5.21 \\
\hline Val & 6.53 & 6.31 \\
\hline Met & 1.81 & 1.78 \\
\hline Ile & 5.10 & 4.92 \\
\hline Leu & 8.83 & 8.65 \\
\hline Phe & 5.45 & 5.33 \\
\hline His & 1.82 & 1.86 \\
\hline Lys & 4.29 & 4.51 \\
\hline Arg & 5.61 & 5.58 \\
\hline Asp & 10.74 & 10.60 \\
\hline Ser & 4.59 & 4.71 \\
\hline Glu & 12.09 & 11.71 \\
\hline Pro & 5.74 & 5.64 \\
\hline Gly & 5.71 & 5.64 \\
\hline Ala & 7.13 & 7.06 \\
\hline Cys & 1.25 & 1.26 \\
\hline Tyr & 3.60 & 3.39 \\
\hline Area $\left(\mathrm{m}^{2} /\right.$ cow/day $)$ & $60.1 \pm 7.4$ & $74.6 \pm 17.1$ \\
\hline Stocking rate (cows/ha) & 6.00 & 4.95 \\
\hline DM offered ( $\mathrm{kg} /$ cow/day) & $17.5 \pm 1.2$ & $21.2 \pm 4.7$ \\
\hline
\end{tabular}

'OM digestibility $=0.72 \times$ cellulase digestibility +23.36 (Aufrère and Demarquilly, 1989).

\section{Statistical analysis}

Data were analyzed according to a split-plot design using the following model:

$Y_{i j k l}=$ mean $+A_{i}+C_{1}+P_{j}\left(C_{1}\right)+M_{k}+M_{h} * C_{1}+e_{i j k l}$ where $A_{i}=$ animal effect $(i=1$ to 36$), P_{j}=$ period effect ( $\mathrm{j}=1$ to 2) within cycle, $\mathrm{M}_{\mathrm{k}}=$ methionine effect ( $k=1$ to 2$), C_{1}=$ cycle effect ( $l=1$ to 2$)$, $\mathrm{e}_{\mathrm{ijkl}}=$ error term. All data were analyzed using the GLM procedure of SAS (1987). 
Table III. Lactational responses to rumen-protected Met at grazing.

\begin{tabular}{lccc}
\hline & Control & Rumen-protected Met & RSD \\
\hline Milk yield $(\mathrm{kg})$ & 26.5 & $26.0 * *$ & 1.06 \\
$4 \%$ FMC $(\mathrm{kg})$ & 25.4 & 25.1 & 1.16 \\
Fat yield $(\mathrm{g})$ & 991 & 983 & 56.6 \\
Protein yield $(\mathrm{g})$ & 803 & 809 & 31.5 \\
Milk fat content $(\mathrm{g} / \mathrm{kg})$ & 37.6 & 38.0 & 1.56 \\
Milk true protein content $(\mathrm{g} / \mathrm{kg})$ & 30.6 & $31.4 * *$ & 0.59 \\
Body weight $(\mathrm{kg})$ & 607 & 607 & 10.1 \\
Concentrate intake $(\mathrm{kg} \mathrm{DM})$ & 3.4 & 3.4 & 0.14 \\
\hline
\end{tabular}

** Statistical significance $P<0.01$

\section{RESULTS AND DISCUSSION}

\section{Grazing conditions}

Grazing went on under good dietary conditions throughout the trial. Indeed, the animals ate 28 - and 26-day-old grass, .15 .6 to $14.7 \mathrm{~cm}$ high, during both cycles (table II). These values matched the optimal regrowth parameters for rye-grass use (Peyraud et al, 1996).

The biomass available per hectare over the two cycles ( 2954 and 2997 tonnes/ha) were practically identical (table II) and widely sufficient for the animal's production level (Delaby et al, 1996). Indeed, considering the stocking rate chosen, the biomass available per cow was between 17.5 and $21.2 \mathrm{~kg} \mathrm{DM} /$ cow/day during the second and third cycles (table II). The biomass available during the third cycle was increased to take account of previous refusal left-overs.

The organic matter and $\mathrm{CP}$ content were the same between the two cycles (table II). The 19\% CP content was consistent with the values commonly obtained with the fertilization level (N/ha) currently applied in Britanny (Peyraud et al, 1996). The ADF and NDF contents slightly increased between the two cycles (table II). This was mainly due to the presence of more refusals from previous grazing, therefore of older grass, in the grass available during the third cycle. The amino acid composition did not vary between the two cycles.

\section{Effects of rumen-protected methionine supplementation on dairy performance}

The responses to protected methionine supplementation did not significantly differ between the two cycles and only the mean responses of both cycles are discussed.

Supplementation of protected methionine induced a slight but significant decrease $(-0.5 \mathrm{~kg} / \mathrm{day} ; P<0.01)$ in milk yield (table III). That was accompanied by a non-significant increase in milk fat content $(+0.4 \mathrm{~g} / \mathrm{kg})$ and protein content $(+0.8 \mathrm{~g} / \mathrm{kg})$, of which only the latter was statistically significant (table III). This increase was mainly due to the reduction in milk yield because the protected methionine added had no effect on fat and protein yields. Methionine supplementation had no effect on the concentrate intake amounts and on the animals' live weight (table III). These responses were similar to those obtained by Brunschwig et al (1995) with cows grazing rye-grass and white clover. These authors recorded a decrease in milk yield of $0.6 \mathrm{~kg} /$ day and an increase in protein content of $0.7 \mathrm{~g} / \mathrm{kg}$ as a response to $12 \mathrm{~g}$ protected methionine sup- 
plementation. More research is needed to explain the decrease of milk yield.

In the blood, protected methionine supplementation significantly increased the plasma methionine level by $27 \%(0.30 \mathrm{vs}$ $0.38 \mathrm{mg} / 100 \mathrm{~mL} ; P<0.05$ ), which demonstrated the effectiveness of the protection used. Other amino acids, by contrast, were not significantly affected.

\section{Nutritional balance estimates}

In pasture, as well as with grass-based diets, the protein yield response to protected methionine supplementation was lower than classically observed with maize silage (25 to $40 \mathrm{~g} /$ day) (Rulquin, 1992). The nutritional balances worked-up with hay or grass silagebased diets permit proposing hypotheses to explains these differences: lower energy level, presence of other limiting amino acids (Le Henaff, 1991).

The main difficulty in establishing such balances at grazing is to secure the proper estimate of the amount and quality of the grass ingested. It is possible to compute the amount of grass intake when the grass is abundant and of good quality, by assuming that the total amount of energy supplied covers the animal's energy requirements. To take the additional energy expenditure linked to grazing into account, the maintenance requirements were increased by $20 \%$ (Inra, 1987). The nutritional value of grass was computed from standard chemical analyses, determination of organic matter digestibility $(\mathrm{dMO})$ and theoretical degradability in the rumen (Andrieu and Demarquilly, 1987). During the third cycle, to take the differences between the grass available and the grass intake into account (presence of leftovers from previous grazing), the $\mathrm{dMO}$ was corrected according to the formula proposed by Peyraud et al (1992).

All these computations led to estimated grass intake amounts of $14.0 \mathrm{~kg}$ DM in both groups. This value was much lower than the amounts available ( $19 \mathrm{~kg} \mathrm{DM})$. It was close to that calculated (14.6 $\mathrm{kg} \mathrm{DM})$ with the equation published by Peyraud et al (1995):

DM intake $=-36.4+0.266$ milk yield +0.86 body weight +0.46 offered grass volume $\left(\mathrm{m}^{3} /\right.$ cow $/$ day $)+0.29$ grass height at entrance $(\mathrm{cm})+0.39$ cellulase digestibility $(\%)$.

With such a intake, $120 \%$ of the PDI requirements would be covered. By comparison with winter diets, that PDI level was highly sufficient to permit clear expression of the responses to limiting amino acid supplementation (Rulquin et al, 1994). The intestinal contents of digestible Lys and Met (LysDI and MetDI) calculated from food analysis according to Rulquin et al (1993) were 6.86 and $1.85 \%$ in the control group and 6.83 and $2.18 \%$ in the supplemented group, respectively. According to the formulas proposed by Rulquin et al (1993), the increase in MetDI should have increased protein yield by $26 \mathrm{~g}$ and the protein content by $0.7 \mathrm{~g} / \mathrm{kg}$. The recorded protein content response was the same as calculated, but protein yield response was 4.3-fold lower than expected. The LysDI concentration did not appear to be the cause for the lowest response recorded. Indeed, that concentration was similar to that observed with maize-based diets, where methionine supplementation increases milk protein yield $2.5 \mathrm{~g}$ for each additional gram of absorbable methionine (Rulquin and Delaby, 1994).

It may be that with grass the levels of response to protected methionine supplementation are limited by the existence of another 'limiting' amino acid, which could be leucine. Indeed in pasture, LeuDI concentrations (Rulquin, unpublished) are lower than with maize-based diets ( 8.46 vs $9.50 \%$ ) and above all they are lower than the optimal concentrations, which should be between 8.8 and $11.1 \%$ (Rulquin, unpublished). The hypothesis of another limiting amino acid was partially confirmed by the increases in yield obtained by Delaby et al (1996) under 
similar grazing conditions with protected soybean meal supplementation.

\section{CONCLUSION}

Under grazing conditions, performance (quantity and quality) of high producing dairy cows have previously been improved by by-pass protein supplements (Delaby et al, 1996). Considering the calculated intestinal fluxes of each amino acid, methionine was supposed to cause that improvement. However, this trial has shown that methionine appears not to be the first limiting amino acid in these conditions.

\section{ACKNOWLEDGMENTS}

The authors are grateful to the Méjusseaume farm personnel (Inra SRVL, Saint-Gilles) for their efficiency in performing the measurements. Translation: Philip Rousseau-Cunningham. The present work was supported financially by Rhône-Poulenc Animal Nutrition, Commentry, France.

\section{REFERENCES}

Andrieu J, Demarquilly C (1987) Valeur nutritive de fourrages: tables et prévision. Bull Tech $C R Z V$ Theix, Inra 70, 61-73

Aufrère J, Demarquilly C (1989) Predicting organic matter digestibility of forage by two pepsin-cellulase methods. XVI Congrès international des herbages, 4-11 octobre (AFPF, ed), Nice, France, 877-878

Brunschwig P, Bareille S, Demerle P, Lecam O, Mathieu Y, Tanan K, Sloan B (1995) Effets d'une supplémentation en méthionine protégée sur des vaches laitières au pâturage. Renc Rec Ruminants 2, 250

Delaby L, Peyraud JL, Vérité R, Marquis B (1996) Effect of protein content in the concentrate and level of nitrogen fertilization on the performance of dairy cows in pasture. Ann Zootech 45, 327-34l

Giger S, Pochet S (1987) Méthodes d'estimation des constituants pariétaux dans les aliments destinés aux ruminants. Bull Tech CRZV Theix, INRA 70 , 49-60

Girdler CP, Thomas PC, Chamberlain DG (1988a) Effect of abomasal infusions of amino acids or a mixed animal protein source on milk production in the dairy cows. Proc Nutr Soc 47,50A
Girdler CP, Thomas PC, Chamberlain DG (1988b) Effects of rumen-protected methionine and lysine on milk production from cows given grass silage diets. Proc Nutr Soc 47, 82A

Inra ( 1987) Alimentation des ruminants. Révision des systèmes et des tables de l'Inra. Bull Tech CRZV Theix, Inra 70, $222 \mathrm{p}$

Le Henaff L (1991) Importance des acides aminés dans la nutrition des vaches laitières. Thèse université Rennes I, $125 \mathrm{p}$

Le Henaff L, Rulquin H, Vérité R ( 1990) Lactational responses to postruminal infusions of amino acids in dairy cows fed maize silage, hay or grass silage. Reprod Nutr Dev suppl 2, 237s (abstract)

Peyraud JL, Comeron EA, Wade MH, Lemaire G (1996) The effect of daily herbage allowance, herbage mass and animal factors upon herbage intake by grazing dairy cows. Ann Zootech 45, 201-217

Peyraud JL, Delaby L, Pecatte JR, Bouttier A (1992) Effet de la réduction de la fertisation azotée sur la qualité de l'herbe sélectionnée par les vaches laitières. Compte rendu des journées AFPF, $128-129$

Peyraud JL, Delagarde R, Delaby L (1995) Influence des conditions d'exploitation du pâturage et des caractéristiques animales sur les quantités ingérées par les vaches laitières: analyse et prédiction. Renc Rec Ruminants 2, 37-44

Pisulewski PM, Rulquin H, Peyraud JL, Vérité R (1996) Lactational and systemic responses to postruminal infusions of increasing amounts of methionine in dairy cows. J Dairy Sci 79, 1781-1791

Rulquin H (1992) Intếrêts et limites d'un apport de méthionine et de lysine dans l'alimentation des vaches laitières, Inra Prod Anim 5, 29-36

Rulquin H. Delaby L (1994) Lactational responses of dairy cows to graded amounts of rumen-protected methionine. J Dairy $S_{c i} 72$ (suppl 1), 91 (abstract)

Rulquin H, Hurtaud C, Delaby L (1994) Effects of dietary protein level on lactational responses of dairy cows to rumen-protected methionine and lysine. Ann Zootech 43, 245

Rulquin H, Pisulewski PM, Vérité R, Guinard J (1993) Milk production and composition as a function of postruminal lysine and methionine supply: a nutrient-response approach. Livest Prod Sci 37, 69-90

Sas (1987) SAS User's guide: Statistics. Version 6 Edition, SAS Inst, Inc, Cary, NC

Urban B, Caudal JP (1990) Herbomètre automatisé. In: Les journées de la mesure. Électronique, Informatique, Automatique, 3-4 Octoher (Inra Dépt Informatique, ed), Port Leucate, 57-59

Van Soest PJ, Wine RH (1967) Use of detergents in the analysis of fibrous feeds. IV. Determination of plant cell-wall constituents. $J$ Assoc Off Anal Chem $50,50-55$ 